\title{
MEASUREMENT AND INTERPRETATION OF SUBCUTANEOUS FAT, WITH NORMS FOR CHILDREN AND YOUNG ADULT MALES
}

BY

\author{
W. H. HAMMOND \\ Ministry of Health, London
}

There is need for a simple and accurate measurement of surface body fat in view of the importance of this tissue from the nutritional and other points of view. Thus body fat, or its change, reflects the balance of an individual's energy intake and output, and this energy balance has been found to be the main determining factor in nutritional adequacy-at least in European countries (Berry, 1951). Apart also from the funetional aspect of body fat as an energy reserve and as a thermal insulator, it appears to be related to the tendency towards the development of certain diseases and freedom from others (Draper, 1924; Freeman, 1934), and its excess is associated with a reduced expectation of life. Surface fat has also been shown to be one of the chief distinguishing features of physical types (Hammond, 1953a). It would be useful, therefore, to have a convenient and accurate measurement of surface fat and also to have standards against which to compare observed results.

Some inferences can be made concerning body fat from the relations between certain body measurements and weight or from the changes in these measurements. Specific gravity of the body is also claimed to indicate body fat. However, at the best, these are indirect measurements, which are complicated in the former case by growth and physical type, and in the latter by variations in the "lean body mass". In adults, changes in weight are mainly due to loss or gain in fat so that these two functions over-lap to a considerable extent (Edwards, 1950), but in children, weight, growth, and fat need to be considered separately. In addition to caliper measurements of body fat, other possible methods include measurement of fat thickness from $x$-ray plates, and estimation of body fat from biochemical changes involved in fat metabolism.

If we confine ourselves to the caliper measurement of subcutaneous fat, the major problems are those of measuring the skinfold accurately at any one point and of determining the number of sites required in order to assess the total surface fat. We also need to know how caliper measurements of body fat vary between the sexes and at different ages, and finally it would be useful to be able to translate the caliper measurements into actual amounts of subcutaneous fat present.

The present paper, therefore, gives the mean caliper measurements for boys aged 2-18 years, a group of adult male factory workers, and girls aged 2-15 years, taken at six sites which have been found to be representative of the results obtained from many sites. The results have also been translated into terms of actual fat thickness as indicated by uncompressed fold thickness measured from $x$-ray photographs.

\section{EXPERIMENTAL MethoD}

For those not familiar with the technique of taking fat measurements the procedure is to lift a fold of skin and subcutaneous tissue clear of the underlying (muscle) tissue between the thumb and forefinger of the left hand, at the same time applying the spring calipers pincerfashion to the parallel-sided fold so produced. (See Plate 1, p. 143, Edwards, Hammond, Healy, Tanner, and Whitehouse, 1955).

In order that the measurements obtained by different observers should be comparable, they must be taken in a standard way at recognized sites using an instrument whose degree of compression of the fold is known. As a result of a number of trials extending over several years, a new dial-type caliper has been produced, known as the M.R.C. or Harpenden skin-fold caliper, having plate sizes $6 \times 15 \mathrm{~mm}$. and pressure $10 \mathrm{~g} / \mathrm{mm} .^{8}$

This instrument, and also a modified Franzen-type spring-caliper studied in the above report by Edwards and others, were used in the present study. The results obtained with the earlier Franzen caliper were calibrated against the new caliper in producing the means, etc., of Table IV.

Details of the sites used are given in the Appendix. They are similar to those used at various times by Edwards (1950), Berry and Cowin (1951), Hammond (1953a), and Edwards and others (1955), with certain additions.

Accuracy of Measuring Technique.-Three separate tests of accuracy were applied during the collection of the present data by the author (who also took part in the trials reported by Edwards and others). As the instruments used were of the same type, and as the levels of accuracy obtained in the present trials agreed fairly closely with the above, summarized results only are presented. Joint trials were also undertaken with Drs. 
TABLE I

STANDARD DEVIATION OF MEASURING DIFFERENCES (mm.)

\begin{tabular}{|c|c|c|c|c|c|c|c|c|}
\hline Caliper & Observers & Biceps & Triceps & Sub-scapular & Supra-iliac & Sub-costal & Abdominal & Subjects \\
\hline \multirow{3}{*}{ Franzen } & \multirow{2}{*}{ Different } & 0.95 & 0.89 & $0 \cdot 81$ & $1 \cdot 59$ & 一 & $1 \cdot 09$ & 60 boys \\
\hline & & $0 \cdot 50$ & 0.97 & 0.96 & - & 0.67 & $1 \cdot 02$ & 47 boys and girls \\
\hline & Same & 0.63 & $0 \cdot 77$ & - & - & - & - & 60 boys and girls \\
\hline M.R.C. & Same & 0.54 & 0.72 & $0 \cdot 38$ & $0 \cdot 50$ & 0.60 & 0.60 & 34 boys \\
\hline
\end{tabular}

Berry and Cowin (who contributed many of the measurements in the table of norms) to ensure that our measuring standards were comparable. One difference between the present trials and those reported by Edwards and others was that the results given in Table I were obtained with unmarked sites and therefore differences of location contributed to the errors (this is especially true of the triceps and supra-iliac sites where small differences in position affect the measurements considerably).

\section{(1) Choice of Measuring Sites ANd Assessment of}

\section{THEIR REPRESENTATIVENESS}

The usual purpose of reporting fat measurements is to indicate the general level of surface body fat rather than the particular reading at any one site, hence it is necessary that the site measurements should apply (with appropriate conversion) to the body as a whole.

If an adequate external criterion of total body fat (or of surface fat) were available to use as a standard, - it would be possible to compare the skinfold measurements obtained at any site with this figure, but in the absence of such information it is necessary to use an internal criterion. The validity or representativeness of different sites can be determined by correlating the results for different measurements with each other or with the sum of the measurements taken at a number of sites. An alternative procedure is to see to what extent a general factor underlies all the measurements and then to determine which measurements indicate this factor most closely; in the same way intelligence is determined as a factor underlying a number of intellectual tests, each of which is an imperfect measure of the factor itself. The factor so derived is really a kind of weighted average in place of the simple total of fat measurements. A measurement can be representative of the total surface fat present, or it can be diagnostic of changes in body fat. Both these aspects have been investigated by correlating batteries of fat measurements and also by correlating changes in these measurements.

SAMPLE.-The correlations were based on groups of children or adults drawn from the following sources:
(1) Leeds babies followed up from 1 to 5 years (Hammond, 1952).

(2) Children aged 5 to 15 years attending council schools in poor, average, and good areas of a number of towns (Hammond, 1953b).

(3) Children aged 5 to 17 years attending independent fee-paying schools, including boarders and day-scholars (Hammond, 1953b).

(4) Children aged 3 to 19 years attending a branch of the National Children's Home.

(5) Children aged 7 to 17 years attending an open-air school for debilitated children, together with a normal control group.

(6) Adult women hospital patients, excluding those with endocrine disorders (Edwards, 1950).

The numbers in each group are given in the Tables of results.

Most of the cross-sectional measurements were based on different children at the different ages, but a few (less than 5 per cent) of the same children appeared in different age groups. The analysis of changes in body fat was made on children of Groups 4 and 5 above. Age norms for measurements at six sites were obtained on the above groups together with five sites for a group of factory workers in light industry (Berry and Cowin, 1954). The total number of subjects was just over 4,500. In no case was there any special selection within the school or group (except that children suffering from specific diseases in Group 5 above were excluded).

In two age groups the children were drawn mainly from the higher social classes and in these cases the results have been weighted to conform to the social distribution of the rest of the sample (i.e. composed mainly of council school children). Similarly the results from clinically poor groups were never allowed to contribute more than 15 per cent. of any age group.

\section{RESULTS}

Relations between Fat Measurements at Different Sites.-The eight tables of correlations between fat measurements for the different groups are available from the author if required. 
Table II (below) gives saturation coefficients for the general factors obtained from these Tables, and the correlations between each measurement and the sum of all the measurements.

Table III (below) gives corresponding saturations for the general factor for changes in body fat and the correlations between the individual measurement changes and the sum of all the changes.

The correlations for all ages are remarkably high [average $r=0.75(0.63$ to 0.84$)$ ], showing that the influences of conditions specific to any one region, as, for example, the effect of exercising the underlying muscles, is small compared with the overall differences. On average, the variance of the general factor accounts for 75 (63 to 84 per cent.) of the total variance. In fact, the fat measurements at different sites show such close agreement that almost any one measurement could be substituted for the rest without great loss. Correlations between single sites and total fat are of the order $0 \cdot 8$ to $0 \cdot 9$, and

TABLE II

GENERAL FACTOR SATURATIONS AND CORRELATIONS BETWEEN FAT MEASUREMENTS AT EACH SITE AND THE TOTALS OF ALL MEASURING SITES

\begin{tabular}{|c|c|c|c|c|c|c|c|c|c|c|c|}
\hline \multirow{2}{*}{$\frac{\text { Sex. } \quad . \quad \ldots}{\text { Age Group (yrs) }}$} & \multirow{2}{*}{$\begin{array}{l}\cdots \\
\cdots\end{array}$} & \multirow{2}{*}{$\cdots$} & \multirow{2}{*}{$\cdots$} & \multicolumn{4}{|c|}{ Male } & \multicolumn{4}{|c|}{ Female } \\
\hline & & & & 6 & $7-11$ & $9-12$ & $15-18$ & $7-11$ & $16-29$ & $30-44$ & $45+$ \\
\hline $\begin{array}{l}\text { Forearm } \\
\text { (outside) }\end{array}$ & & $\begin{array}{l}\text { Saturation } \\
\text { Correlation }\end{array}$ & $\begin{array}{l}. . \\
.\end{array}$ & 二 & $=$ & 0.955 & 0.915 & $=$ & $\begin{array}{l}0.915 \\
0.914\end{array}$ & $\begin{array}{l}0.654 \\
0.663\end{array}$ & $\begin{array}{l}0 \cdot 703 \\
0 \cdot 764\end{array}$ \\
\hline (inside) & & $\begin{array}{l}\text { Saturation } \\
\text { Correlation }\end{array}$ & $\because$. & $=$ & $=$ & $\begin{array}{c}0.968 \\
-\end{array}$ & $\begin{array}{c}0.881 \\
-\end{array}$ & $=$ & $=$ & 二 & $=$ \\
\hline Biceps & & $\begin{array}{l}\text { Saturation } \\
\text { Correlation }\end{array}$ & .. & $\begin{array}{l}0.802 \\
0.757\end{array}$ & $\begin{array}{l}0.911 \\
0.911\end{array}$ & $\stackrel{0.898}{-}$ & 0.908 & $\begin{array}{l}0.884 \\
0.889\end{array}$ & 二 & 二 & 二 \\
\hline Triceps & & $\begin{array}{l}\text { Saturation } \\
\text { Correlation }\end{array}$ & $\begin{array}{l}. \\
.\end{array}$ & $\begin{array}{l}0 \cdot 713 \\
0.760\end{array}$ & $\begin{array}{l}0.856 \\
0.897\end{array}$ & $0 \cdot 880$ & $\stackrel{0 \cdot 881}{-}$ & $\begin{array}{l}0.867 \\
0.889\end{array}$ & $\begin{array}{l}0.912 \\
0.901\end{array}$ & $\begin{array}{l}0.866 \\
0.851\end{array}$ & $\begin{array}{l}0.850 \\
0.834\end{array}$ \\
\hline Sub-scapular & & $\begin{array}{l}\text { Saturation } \\
\text { Correlation }\end{array}$ & 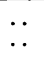 & $\begin{array}{l}0.772 \\
0.789\end{array}$ & $\begin{array}{l}0.896 \\
0.942\end{array}$ & $\overline{-}$ & 二 & $\begin{array}{l}0.907 \\
0.881\end{array}$ & $\begin{array}{l}0.955 \\
0.947\end{array}$ & $\begin{array}{l}0.947 \\
0.936\end{array}$ & $\begin{array}{l}0.926 \\
0.900\end{array}$ \\
\hline Supra-iliac & & $\begin{array}{l}\text { Saturation } \\
\text { Correlation }\end{array}$ & .. & 二 & $\begin{array}{l}0.891 \\
0.943\end{array}$ & 二 & - & $\begin{array}{l}0.912 \\
0.890\end{array}$ & $\begin{array}{l}0.913 \\
0.914\end{array}$ & $\begin{array}{l}0.867 \\
0.878\end{array}$ & $\begin{array}{l}0.805 \\
0.768\end{array}$ \\
\hline Sub-costal & & $\begin{array}{l}\text { Saturation } \\
\text { Correlation }\end{array}$ & $\because$. & $\begin{array}{l}0.820 \\
0.811\end{array}$ & - & 二 & 二 & 二 & $\begin{array}{l}0.874 \\
0.879\end{array}$ & $\begin{array}{l}0.871 \\
0.877\end{array}$ & $\begin{array}{l}0.850 \\
0.862\end{array}$ \\
\hline Abdominal & & $\begin{array}{l}\text { Saturation } \\
\text { Correlation }\end{array}$ & $\because$ & $\begin{array}{l}0.849 \\
0.852\end{array}$ & $\begin{array}{l}0.933 \\
0.958\end{array}$ & $\begin{array}{c}0.915 \\
-\end{array}$ & 0.642 & $\begin{array}{l}0.920 \\
0.894\end{array}$ & $\begin{array}{l}0.940 \\
0.931\end{array}$ & $\begin{array}{l}0.876 \\
0.869\end{array}$ & $\begin{array}{l}0.911 \\
0.889\end{array}$ \\
\hline Thigh & & $\begin{array}{l}\text { Saturation } \\
\text { Correlation }\end{array}$ & .. & 二 & $\begin{array}{l}0.883 \\
0.954\end{array}$ & 二 & $\begin{array}{c}0.641 \\
-\end{array}$ & $\begin{array}{l}0.889 \\
0.858\end{array}$ & $\begin{array}{l}0.830 \\
0.860\end{array}$ & $\begin{array}{l}0.853 \\
0.856\end{array}$ & $\begin{array}{l}0.810 \\
0.859\end{array}$ \\
\hline Chest & & $\begin{array}{l}\text { Saturation } \\
\text { Correlation }\end{array}$ &.. & 二 & 二 & $\begin{array}{c}0.878 \\
-\end{array}$ & $\begin{array}{c}0.715 \\
-\end{array}$ & $=$ & $\begin{array}{l}0.898 \\
0.886\end{array}$ & $\begin{array}{l}0.830 \\
0.817\end{array}$ & $\begin{array}{l}0.854 \\
0.822\end{array}$ \\
\hline Number Examined & & .. & . & 346 & 401 & 31 & 100 & 400 & 58 & 52 & 46 \\
\hline
\end{tabular}

TABLE III

MEAN GENERAL FACTOR SATURATIONS FOR ANNUAL CHANGES IN BODY FAT AND CORRELATIONS WITH TOTAL FAT CHANGE

\begin{tabular}{|c|c|c|c|c|c|c|c|c|c|c|c|c|c|}
\hline \multirow{2}{*}{$\frac{\operatorname{Sex}}{\text { Age Group (yrs) }}$} & \multirow{2}{*}{$\frac{\cdots}{\cdots}$} & \multirow{2}{*}{$\ddot{-}$} & \multirow{2}{*}{$\frac{\cdots}{\cdots}$} & \multirow{2}{*}{$\cdots$} & \multicolumn{5}{|c|}{ Male } & \multicolumn{4}{|c|}{ Female } \\
\hline & & & & & 4 & 4-8 & $8-11$ & $11-14$ & $14+$ & 4 & $4-9$ & $10-12$ & $12-14$ \\
\hline Biceps & $\begin{array}{l}\text { Sat } \\
\text { Co }\end{array}$ & $\begin{array}{l}\text { turation } \\
\text { rrelation }\end{array}$ &.. & $\begin{array}{l}. . \\
.\end{array}$ & $\begin{array}{l}0.488 \\
0.543\end{array}$ & $\begin{array}{l}0.683 \\
0.765\end{array}$ & $\begin{array}{l}0.844 \\
0.914\end{array}$ & $\begin{array}{l}0.679 \\
0.759\end{array}$ & $\begin{array}{l}0.527 \\
0.561\end{array}$ & $\begin{array}{l}0.400 \\
0.465\end{array}$ & $\begin{array}{l}0.678 \\
0.739\end{array}$ & $\begin{array}{l}0.676 \\
0.695\end{array}$ & $\begin{array}{l}0 \cdot 709 \\
0 \cdot 818\end{array}$ \\
\hline Triceps & $\begin{array}{l}\text { Sat } \\
\text { Co }\end{array}$ & $\begin{array}{l}\text { uration } \\
\text { rrelation }\end{array}$ & $\therefore$ & $\because$. & $\begin{array}{l}0 \cdot 340 \\
0 \cdot 521\end{array}$ & $\begin{array}{l}0.744 \\
0.790\end{array}$ & $\begin{array}{l}0.673 \\
0.791\end{array}$ & $\begin{array}{l}0.826 \\
0.918\end{array}$ & $\begin{array}{l}0.592 \\
0.739\end{array}$ & $\begin{array}{l}0.673 \\
0.701\end{array}$ & $\begin{array}{l}0.836 \\
0.927\end{array}$ & $\begin{array}{l}0.687 \\
0.700\end{array}$ & $\begin{array}{l}0.705 \\
0.836\end{array}$ \\
\hline Sub-scapular & $\begin{array}{l}\text { Sat } \\
\text { Co }\end{array}$ & $\begin{array}{l}\text { turation } \\
\text { rrelation }\end{array}$ & $\therefore$ & 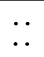 & $\begin{array}{l}0.939 \\
0.943\end{array}$ & $\begin{array}{l}0.644 \\
0.700\end{array}$ & $\begin{array}{l}0.750 \\
0.832\end{array}$ & $\begin{array}{l}0.816 \\
0.913\end{array}$ & $\begin{array}{l}0.565 \\
0.616\end{array}$ & $\begin{array}{l}0.492 \\
0.571\end{array}$ & $\begin{array}{l}0.663 \\
0.720\end{array}$ & $\begin{array}{l}0.760 \\
0.834\end{array}$ & $\begin{array}{l}0.692 \\
0.732\end{array}$ \\
\hline Supra-iliac & & $\begin{array}{l}\text { turation } \\
\text { rrelation }\end{array}$ & $\ldots$ & 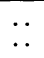 & $\begin{array}{l}0.781 \\
0.803\end{array}$ & $\begin{array}{l}0.544 \\
0.724\end{array}$ & $\begin{array}{l}0.881 \\
0.882\end{array}$ & $\begin{array}{l}0.784 \\
0.854\end{array}$ & $\begin{array}{l}0.337 \\
0.459\end{array}$ & $\begin{array}{l}0.866 \\
0.779\end{array}$ & $\begin{array}{l}0.511 \\
0.616\end{array}$ & $\begin{array}{l}0.667 \\
0.814\end{array}$ & $\begin{array}{l}0.498 \\
0.641\end{array}$ \\
\hline Sub-costal & $\begin{array}{l}\text { Sat } \\
\text { Co }\end{array}$ & $\begin{array}{l}\text { turation } \\
\text { rrelation }\end{array}$ & $\therefore$ & 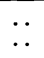 & $\begin{array}{l}0 \cdot 817 \\
0 \cdot 864\end{array}$ & 二 & 二 & 二 & 二 & $\begin{array}{l}0.519 \\
0.626\end{array}$ & 二 & $=$ & 二 \\
\hline Abdominal & $\begin{array}{l}\text { Sat } \\
\text { Co }\end{array}$ & $\begin{array}{l}\text { uration } \\
\text { rrelation }\end{array}$ & $\because$. & $\because$ & $\begin{array}{l}0.973 \\
0.951\end{array}$ & $\begin{array}{l}0.728 \\
0.819\end{array}$ & $\begin{array}{l}0.823 \\
0.895\end{array}$ & $\begin{array}{l}0.690 \\
0.770\end{array}$ & $\begin{array}{l}0.750 \\
0.877\end{array}$ & $\begin{array}{l}0.430 \\
0.671\end{array}$ & $\begin{array}{l}0.593 \\
0.750\end{array}$ & $\begin{array}{l}0.796 \\
0.827\end{array}$ & $\begin{array}{l}0.774 \\
0.832\end{array}$ \\
\hline Number Examined & & $\ldots$ & $\ldots$ & $\ldots$ & 31 & 33 & 51 & 67 & 36 & 37 & 62 & 44 & 49 \\
\hline
\end{tabular}


the best combinations of two sites in most batteries give multiple correlations of the order 0.95 , whilst three increase the multiple correlation to 0.97 or over.*

Although the best measurements vary somewhat according to the total battery and according to the individuals (male or female, children or adults) the results show that the sub-scapular and abdominal measurements followed by biceps and either subcostal or supra-iliac measurements give the best indication of total fat.

It is worth noting that in the women's measurements the saturations for the general factor for the small battery of tests agree very closely with the correlations between the measurements and the total of 56 measuring sites (Table II), showing that a severe curtailment of the number of measurements has left the diagnostic value of the separate measurements practically unchanged compared with the wider criterion based on measurements taken over the whole of the body.

When the general factor was extracted, the residual variance showed the presence of a secondary factor differentiating between fat deposition on the trunk or on the limbs. All the tables which included limb and trunk measurements supported this distinction without significant exception. The variance of the second factor averaged $3 \cdot 7(1.4$ to $8 \cdot 3$ per cent.) of the total variance. The number of measuring sites tested was rather limited for the purpose of defining a second factor, but the biceps measurement had the highest factor saturation for the limb component in the majority of tables. For the trunk component the measurement with the highest saturation depended upon the combination of trunk measurements used, and the choice of measurements for the purpose of defining the trunk component must, therefore, be left open. A wider selection of sites would be required to deal with the distribution of body fat in any detail, but the appearance of a division into trunk and limb groups suggests that at least one limb and one trunk measurement should be included in any combination intended to be representative of total body fat, since this would cover the most important variation in the pattern of fat distribution.

Changes in Body Fat.-Another and perhaps more important aspect of body fat is its change in individuals over a period. Changes in one individual may be slight compared with the differences between individuals, but they may be more important nutritionally. One could assess a person's total fat

*Detailed results of coefficients and multiple correlations for different combinations of sites are available if required, from the Author, Ministry of Health, Savile Row, London W.1. from the three most representative measurements above and repeat the measurements at intervals along with weight to determine changes in conditions. However, the sites which are most representative of the cross-sectional measurements may not be the best ones to reflect change in total fat or change in weight; hence fat measurements at the five or six sites used in the cross-sectional studies were taken monthly or quarterly for 2 years in two different studies involving groups of children of different ages. The changes at different sites were correlated with each other over the 24 months. As there were in all sixteen tables of correlations these are not reproduced;* instead, the correlations between each site and the sum of the measurement changes from all sites, and also the general factor saturations for each group are reproduced (Table III).

The rather uneven grouping of ages in Tables II and III is due to the fact that the results were collected from a variety of studies undertaken at different times for different purposes. The ranges were chosen to avoid a large scatter in ages at points where the mean measurements were changing. The analysis results from the various groups are reproduced to show the general level of consistency in the behavious of fat measurements at different sites.

Here the changes in each measurement are not as closely related as are the cross-sectional measurements [mean : $r=0.56(0.31$ to 0.75$)$ ], partly because the measuring errors play a greater part. Again, the triceps, scapular and abdominal fat (umbilical region) are the most closely related with the general change (as assessed from the sum of the changes in fat measurement and according to the general factor corresponding to the overall fat change), but the results vary more from group to group. Further, the general factor accounts, on average, for only 49 per cent. of the total variance, compared with 75 per cent for the cross-sectional results.

Measured changes in an individual's subcutaneous fat at any site do not, therefore, indicate total change as closely as the individual measurements represent the present fat rating of the person in relation to a group standard. The practical outcome is that it is more important to use several sites when determining fat changes than when studying crosssectional data. This is also made necessary because the errors of measurement of fat change are considerably higher in relation to the total variance.

Correlations between fat change and weight change in children were low and often negative [mean $r=0.40(-0.39$ to +0.90$)$ ] depending on the sex and ages studied. This is because weight

\footnotetext{
*They are available from the Author.
} 
gain in children is mainly due to growth of muscle and skeleton. Further, the change in the mean body fat does not follow the pattern of weight change with age, for in some children the phenomenon of "bolting" occurs, and growth apparently continues at the expense of body fat as shown by the negative correlations, and in others body fat increases markedly after growth ceases. Even the correlations between change in body fat and weight gain per unit gain in height were centred around zero [mean $r=0.03$ $(-0.24$ to $+0 \cdot 22)]$.

The above results show that the sites which were initially chosen largely for convenience (as entailing a minimum of undressing and discomfort to the subject) and also for ease in making a parallel-sided fold have proved to be highly representative of all measuring sites. We can therefore, be fairly confident that if we measure individuals or groups at these sites the results will give much the same relative positions as if we measured them at many sites.

Although the data are insufficient to be able to say that the particular measuring sites chosen are the best of all the possible ones, yet the fact that these sites are representative of general conditions increases their usefulness. Since, also, these sites have been studied more extensively than any others by other workers (very similar sites have been included among those reported in all the major published studies in this country), there is much value in keeping to these measurements (if necessary with the addition of other sites for particular purposes) for general nutrtional survey work.

\section{(2) Age Norms for Body FAT}

Means and standard errors for caliper measurements taken at six sites studied in different age groups using the standard M.R.C. calipers (or results from Franzen-type calipers transformed to the M.R.C. equivalents) are given in Table IV.

Fig. 1, and Figs 2 and 3 (overleaf), show the age trends for the different fat sites for boys and girls. Sex differences are shown not only in the general amount of body fat but also in the pattern of change with age. Apart from irregular fluctuations, probably due to sampling, the girls decrease very slightly in fat from 2 years to around 5 years, and then increase continuously to age 15 years when the data stop. This is true of all measuring sites but the arm measurements show much slighter increases than the trunk ones. In the case of boys two trends are apparent, one in the trunk fat (Fig. 2), in which measurements decrease to age 7 years then increase rapidly to 11 years and more slowly to 17 years. The

TABLE IV

CALIPER MEASUREMENTS OF SKINFOLD THICKNESS (PRESSURE 10g./mm. ${ }^{2}$ ) FROM AGE 2 ONWARDS

\begin{tabular}{|c|c|c|c|c|c|c|c|c|c|c|c|c|c|c|}
\hline \multirow{3}{*}{$\operatorname{Sex}$} & \multirow{3}{*}{$\underset{\text { (yrs) }}{\text { Age }}$} & \multirow{3}{*}{$\begin{array}{c}\text { Number } \\
\text { Ex- } \\
\text { amined }\end{array}$} & \multicolumn{12}{|c|}{ Measurement Site } \\
\hline & & & \multicolumn{2}{|c|}{ Biceps } & \multicolumn{2}{|c|}{ Triceps } & \multicolumn{2}{|c|}{ Sub-scapular } & \multicolumn{2}{|c|}{ Supra-iliac } & \multicolumn{2}{|c|}{ Sub-costal } & \multicolumn{2}{|c|}{ Abdominal } \\
\hline & & & Mean & s.e. & Mean & s.e. & Mean & s.e. & Mean & s.e. & Mean & s.e. & Mean & s.e. \\
\hline Male & $\begin{array}{c}2 \\
3 \\
4 \\
5 \\
6 \\
7 \\
8 \\
9 \\
10 \\
11 \\
12 \\
13 \\
14 \\
15 \\
16 \\
17 \\
18 \\
\text { Adults }\end{array}$ & $\begin{array}{r}89 \\
28 \\
43 \\
49 \\
399 \\
65 \\
65 \\
130 \\
472 \\
235 \\
162 \\
110 \\
1,056 \\
98 \\
68 \\
275 \\
181 \\
228\end{array}$ & $\begin{array}{l}5 \cdot 59 \\
4 \cdot 99 \\
4 \cdot 94 \\
4 \cdot 50 \\
4 \cdot 31 \\
3 \cdot 94 \\
3 \cdot 86 \\
4 \cdot 13 \\
4 \cdot 06 \\
4 \cdot 55 \\
4 \cdot 10 \\
4 \cdot 20 \\
4 \cdot 19 \\
3 \cdot 32 \\
3 \cdot 41 \\
3 \cdot 58 \\
3 \cdot 11 \\
3 \cdot 22\end{array}$ & $\begin{array}{l}0 \cdot 12 \\
0 \cdot 21 \\
0 \cdot 17 \\
0 \cdot 15 \\
0.05 \\
0 \cdot 15 \\
0 \cdot 15 \\
0 \cdot 11 \\
0 \cdot 06 \\
0 \cdot 10 \\
0 \cdot 12 \\
0 \cdot 10 \\
0.03 \\
0.06 \\
0.08 \\
0.08 \\
0.09 \\
0.09\end{array}$ & $\begin{array}{r}10 \cdot 10 \\
9 \cdot 32 \\
9 \cdot 34 \\
9 \cdot 13 \\
8 \cdot 23 \\
7 \cdot 88 \\
7 \cdot 56 \\
8 \cdot 21 \\
8 \cdot 20 \\
8 \cdot 94 \\
8 \cdot 45 \\
8 \cdot 11 \\
7 \cdot 91 \\
6 \cdot 30 \\
6 \cdot 22 \\
6 \cdot 40 \\
4 \cdot 81 \\
5 \cdot 83\end{array}$ & $\begin{array}{l}0 \cdot 16 \\
0 \cdot 28 \\
0 \cdot 23 \\
0 \cdot 23 \\
0 \cdot 08 \\
0 \cdot 23 \\
0 \cdot 23 \\
0 \cdot 16 \\
0 \cdot 09 \\
0 \cdot 18 \\
0 \cdot 22 \\
0 \cdot 22 \\
0 \cdot 07 \\
0 \cdot 22 \\
0 \cdot 27 \\
0 \cdot 14 \\
0.19 \\
0.18\end{array}$ & $\begin{array}{l}5 \cdot 55 \\
4 \cdot 73 \\
4 \cdot 78 \\
4 \cdot 97 \\
4 \cdot 58 \\
4 \cdot 51 \\
4 \cdot 46 \\
5 \cdot 03 \\
5 \cdot 04 \\
5 \cdot 22 \\
5 \cdot 20 \\
5 \cdot 29 \\
5 \cdot 54 \\
5 \cdot 26 \\
6 \cdot 27 \\
6 \cdot 44 \\
6 \cdot 07 \\
7 \cdot 95\end{array}$ & $\begin{array}{l}0.09 \\
0 \cdot 18 \\
0 \cdot 14 \\
0 \cdot 15 \\
0.05 \\
0 \cdot 17 \\
0 \cdot 17 \\
0.12 \\
0.06 \\
0 \cdot 12 \\
0 \cdot 15 \\
0 \cdot 10 \\
0.03 \\
0.09 \\
0 \cdot 11 \\
0.06 \\
0.09 \\
0.09\end{array}$ & $\begin{array}{l}5 \cdot 12 \\
5 \cdot 05 \\
4 \cdot 62 \\
4 \cdot 61 \\
4 \cdot 39 \\
4 \cdot 35 \\
4 \cdot 29 \\
5 \cdot 12 \\
5 \cdot 05 \\
5 \cdot 21 \\
5 \cdot 22 \\
5 \cdot 24 \\
5 \cdot 23 \\
4 \cdot 94 \\
5 \cdot 45 \\
5 \cdot 52 \\
5 \cdot 00 \\
-\end{array}$ & $\begin{array}{l}0 \cdot 14 \\
0 \cdot 26 \\
0 \cdot 20 \\
0 \cdot 20 \\
0 \cdot 07 \\
0 \cdot 18 \\
0 \cdot 18 \\
0 \cdot 13 \\
0 \cdot 07 \\
0 \cdot 15 \\
0 \cdot 18 \\
0 \cdot 10 \\
0 \cdot 03 \\
0 \cdot 13 \\
0 \cdot 16 \\
0 \cdot 09 \\
0 \cdot 13 \\
0 \cdot 12\end{array}$ & $\begin{array}{l}4 \cdot 53 \\
3 \cdot 65 \\
3 \cdot 57 \\
3 \cdot 74 \\
3 \cdot 70 \\
3 \cdot 40 \\
3 \cdot 54 \\
4 \cdot 50 \\
4 \cdot 28 \\
5 \cdot 09 \\
5 \cdot 22 \\
5 \cdot 20 \\
5 \cdot 17 \\
4 \cdot 78 \\
5 \cdot 26 \\
5 \cdot 84 \\
5 \cdot 14 \\
7 \cdot 81\end{array}$ & $\begin{array}{l}0 \cdot 08 \\
0 \cdot 12 \\
0 \cdot 12 \\
0 \cdot 09 \\
0 \cdot 03 \\
0 \cdot 15 \\
0 \cdot 15 \\
0 \cdot 11 \\
0 \cdot 06 \\
0 \cdot 08 \\
0 \cdot 10 \\
0 \cdot 10 \\
0 \cdot 03 \\
0 \cdot 12 \\
0 \cdot 14 \\
0 \cdot 08 \\
0 \cdot 11 \\
0 \cdot 10\end{array}$ & $\begin{array}{l}6 \cdot 77 \\
5 \cdot 99 \\
5 \cdot 81 \\
5 \cdot 96 \\
4 \cdot 92 \\
4 \cdot 70 \\
5 \cdot 13 \\
5 \cdot 61 \\
5 \cdot 82 \\
6 \cdot 25 \\
5 \cdot 99 \\
5 \cdot 82 \\
6 \cdot 04 \\
5 \cdot 46 \\
6 \cdot 10 \\
7 \cdot 22 \\
5 \cdot 53 \\
8 \cdot 80\end{array}$ & $\begin{array}{l}0 \cdot 19 \\
0 \cdot 36 \\
0 \cdot 28 \\
0 \cdot 27 \\
0 \cdot 09 \\
0 \cdot 24 \\
0 \cdot 24 \\
0 \cdot 17 \\
0 \cdot 09 \\
0 \cdot 16 \\
0 \cdot 20 \\
0 \cdot 16 \\
0 \cdot 05 \\
0 \cdot 19 \\
0 \cdot 23 \\
0 \cdot 12 \\
0 \cdot 16 \\
0 \cdot 15\end{array}$ \\
\hline $\begin{array}{l}\mathrm{Fe}- \\
\text { male }\end{array}$ & $\begin{array}{r}2 \\
3 \\
4 \\
5 \\
6 \\
7 \\
8 \\
9 \\
10 \\
11 \\
12 \\
13 \\
14 \\
15\end{array}$ & $\begin{array}{l}46 \\
38 \\
44 \\
45 \\
39 \\
60 \\
21 \\
80 \\
88 \\
94 \\
68 \\
65 \\
54 \\
30\end{array}$ & $\begin{array}{l}5 \cdot 39 \\
5 \cdot 04 \\
5 \cdot 29 \\
4 \cdot 94 \\
5 \cdot 40 \\
5 \cdot 20 \\
5 \cdot 35 \\
5 \cdot 60 \\
5 \cdot 67 \\
6 \cdot 21 \\
5 \cdot 64 \\
6 \cdot 18 \\
6 \cdot 50 \\
6 \cdot 67\end{array}$ & $\begin{array}{l}0 \cdot 20 \\
0 \cdot 24 \\
0 \cdot 21 \\
0 \cdot 26 \\
0 \cdot 28 \\
0 \cdot 20 \\
0 \cdot 38 \\
0 \cdot 17 \\
0 \cdot 24 \\
0 \cdot 23 \\
0 \cdot 24 \\
0 \cdot 24 \\
0 \cdot 28 \\
0 \cdot 39\end{array}$ & $\begin{array}{r}10 \cdot 90 \\
9 \cdot 70 \\
10 \cdot 24 \\
9.42 \\
9 \cdot 57 \\
9.39 \\
10 \cdot 10 \\
10 \cdot 25 \\
10.36 \\
10.64 \\
10.06 \\
10.40 \\
11 \cdot 27 \\
11 \cdot 35\end{array}$ & $\begin{array}{l}0.34 \\
0.40 \\
0.35 \\
0 \cdot 37 \\
0.39 \\
0 \cdot 31 \\
0.55 \\
0 \cdot 36 \\
0 \cdot 34 \\
0 \cdot 33 \\
0 \cdot 38 \\
0 \cdot 39 \\
0 \cdot 52 \\
0 \cdot 70\end{array}$ & $\begin{array}{r}-\overline{5} \\
5 \cdot 05 \\
5 \cdot 20 \\
5 \cdot 18 \\
5 \cdot 28 \\
5 \cdot 39 \\
6 \cdot 20 \\
6 \cdot 27 \\
6 \cdot 50 \\
7 \cdot 73 \\
7 \cdot 54 \\
8 \cdot 57 \\
9 \cdot 94 \\
10 \cdot 39\end{array}$ & $\begin{array}{l}\overline{0} \cdot 27 \\
0.23 \\
0.33 \\
0.35 \\
0.25 \\
0 \cdot 45 \\
0 \cdot 22 \\
0 \cdot 26 \\
0 \cdot 25 \\
0 \cdot 47 \\
0.48 \\
0.42 \\
0 \cdot 56\end{array}$ & $\begin{array}{l}5 \cdot \overline{5} \\
5 \cdot 30 \\
5 \cdot 12 \\
5 \cdot 65 \\
5 \cdot 94 \\
6 \cdot 41 \\
6 \cdot 80 \\
7 \cdot 04 \\
7 \cdot 92 \\
7 \cdot 37 \\
8 \cdot 88 \\
9 \cdot 26 \\
9 \cdot 95\end{array}$ & $\begin{array}{l}\overline{0} \\
0.35 \\
0.30 \\
0.34 \\
0.35 \\
0.26 \\
0.45 \\
0.22 \\
0.31 \\
0 \cdot 30 \\
0.43 \\
0.44 \\
0.34 \\
0.46\end{array}$ & $\begin{array}{l}-\overline{4} \cdot 33 \\
4 \cdot 20 \\
3 \cdot 97 \\
4 \cdot 60 \\
4 \cdot 55 \\
5 \cdot 07 \\
5 \cdot 34 \\
5 \cdot 08 \\
5 \cdot 69 \\
5 \cdot 95 \\
7 \cdot 14 \\
6 \cdot 83 \\
7 \cdot 50\end{array}$ & $\begin{array}{l}-\overline{0} \\
0 \cdot 18 \\
0 \cdot 16 \\
0 \cdot 23 \\
0 \cdot 25 \\
0 \cdot 19 \\
0 \cdot 30 \\
0 \cdot 16 \\
0 \cdot 30 \\
0 \cdot 28 \\
0 \cdot 43 \\
0 \cdot 44 \\
0 \cdot 39 \\
0 \cdot 51\end{array}$ & $\begin{array}{r}-\overline{6} \\
6 \cdot 80 \\
7 \cdot 20 \\
6 \cdot 18 \\
7 \cdot 60 \\
7 \cdot 08 \\
8 \cdot 06 \\
8 \cdot 39 \\
9 \cdot 31 \\
10 \cdot 88 \\
11 \cdot 32 \\
12 \cdot 45 \\
14 \cdot 42 \\
14 \cdot 14\end{array}$ & $\begin{array}{l}-\overline{0.42} \\
0.37 \\
0.53 \\
0.60 \\
0.48 \\
0.80 \\
0.42 \\
0.46 \\
0.45 \\
0.60 \\
0.61 \\
0.46 \\
0.62\end{array}$ \\
\hline
\end{tabular}




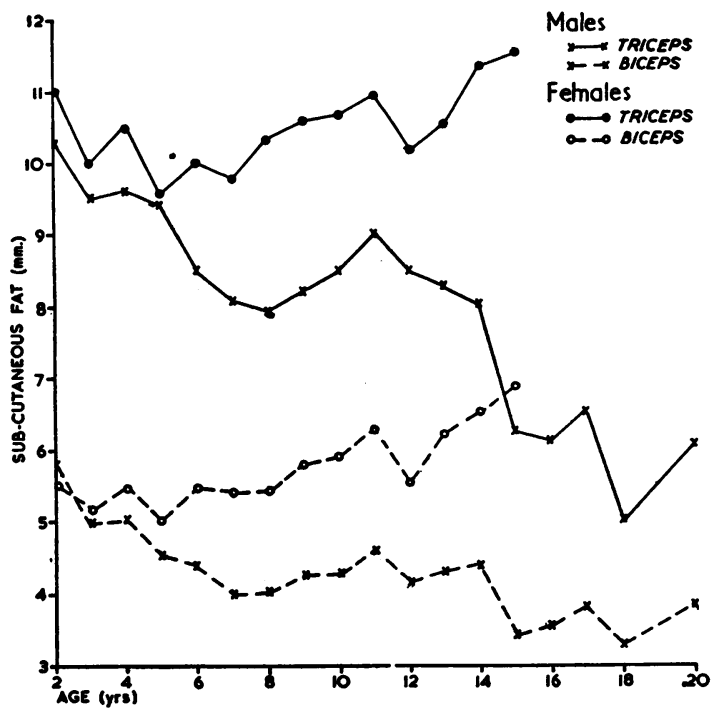

Fig. 1.-Age norms in biceps and triceps fat for males and females. Caliper pressure $10 \mathrm{~g} . / \mathrm{mm} .^{2}$

trend of fat on the arm (Fig. 1) is to decrease to age 8 years, then to show a much slighter rise from age 8 to 11 years, and from 11 to fall slowly at first then more steeply to age 18 years. The difference in behaviour of trunk and arm fat in boys is unlikely to be due to selection. It may be due to a greater concentration of muscle activity in the arm region during late childhood than in early childhood, so depleting the fat there.

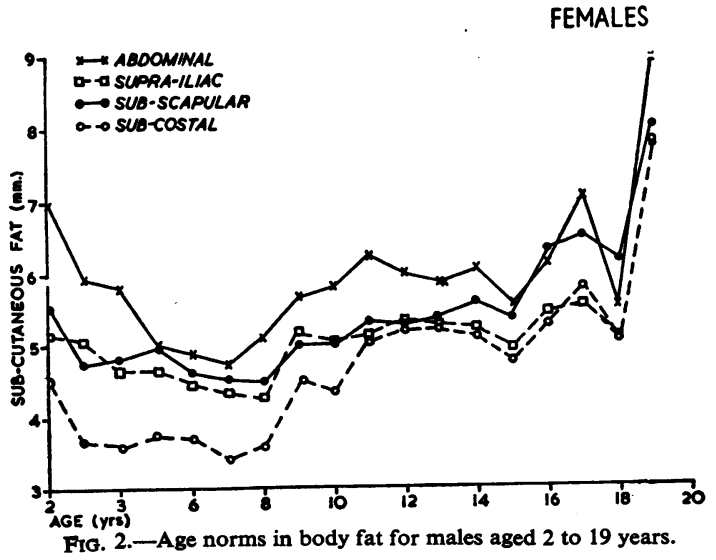

The caliper measurements are positively skewed, in some cases markedly so, and this has given rise to the suggestion of using a logarithmic transformation as is sometimes adopted in measuring weight, in order to produce a more nearly normal distribution (Edwards and others, 1955). The effects of skewness on the interepertation of measurements of fat is referred to below in the discussion.

Relation of Caliper Measurements of Surface Fat to True Fat Thickness.- Since any caliper measurement of surface fat compresses the tissue (either by pressure from the instrument or by lifting the skinfold), the values obtained cannot be treated as absolute measures of fat thickness. However, the thickness of the subcutaneous fat can be measured from soft $x$-ray photographs involving no compression of the tissue.

I have calculated the following regression equation for the actual thickness of surface fat measured from $x$-ray plates in terms of the caliper measurement taken at the same sites*.

Actual subcutaneous fat thickness $(\mathrm{mm})=$. $0.88 x-0.00074 x^{2}$, where $x=$ actual M.R.C.

*Calculated from data kindly provided by Dr. J. M. Tanner and Mr. R. H. Whitehouse from the Harpenden Growth Study (Tanner, 1955).

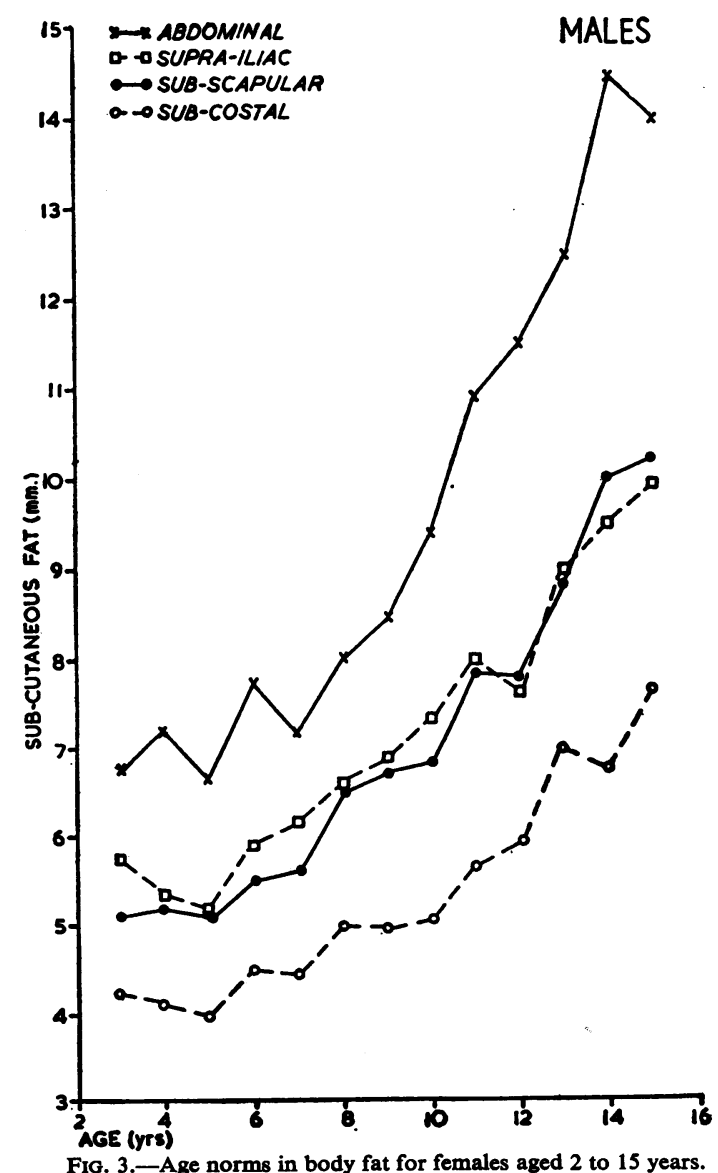


caliper reading. Fig. 4 shows the data in the form of a scatter diagram.

The same relation between caliper and $x$-ray results is given, whether the measuring site is over the biceps, triceps, or thigh, suggesting that though the fat compressibility differs with the amount of the jaw opening it is less dependent upon the site of the tissue measured.

A similar equation for the relation between the $x$-ray results and those obtained with the Franzentype caliper, calculated from an accuracy trial held in 1952, gives results very close to those obtained by the double transformation from Franzen to British Indicators and from British Indicators to $x$-ray results.

Correlations between the Franzen-type caliper readings and the $x$-ray measurements were 0.82 and 0.89 for the thigh, 0.83 and 0.84 for biceps, and 0.89 and 0.90 for triceps, for boys and girls respectively.

The mean measurements at each age transformed to the equivalent true fat thicknesses as given by measurements obtained from $x$-ray plates are shown in Table V.

The figures in Table $\mathrm{V}$ seem to be the best form in which to set out results, since they indicate a true fat

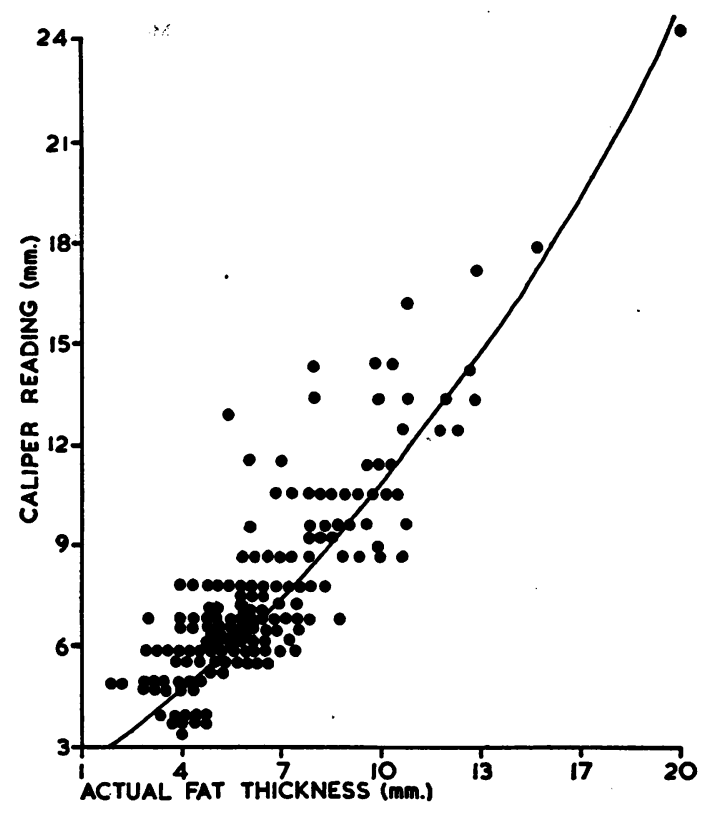

FIG. 4.-Relation between caliper readings of fat thickness and actual fat thickness.

Fat $=0.95 x-0.0074 x^{2}$, where $x=$ reading in tenths of a millimetre

TABLE V

MEASUREMENTS OF BODY FAT AT DIFFERENT SITES

(UNCOMPRESSED FAT THICKNESS)*

\begin{tabular}{|c|c|c|c|c|c|c|c|c|}
\hline \multirow{2}{*}{ Sex } & \multirow{2}{*}{ Age (yrs) } & \multirow{2}{*}{ Number Examined } & \multicolumn{6}{|c|}{ Measurement Site } \\
\hline & & & Biceps & Triceps & Sub-scapular & Supra-iliac & Sub-costal & Abdominal \\
\hline Male & $\begin{array}{c}2 \\
3 \\
4 \\
5 \\
6 \\
7 \\
8 \\
9 \\
10 \\
11 \\
12 \\
13 \\
14 \\
15 \\
16 \\
17 \\
18 \\
\text { Adults }\end{array}$ & $\begin{array}{r}89 \\
28 \\
43 \\
49 \\
399 \\
65 \\
65 \\
130 \\
472 \\
235 \\
162 \\
110 \\
1,056 \\
98 \\
68 \\
275 \\
181 \\
228\end{array}$ & $\begin{array}{l}5 \cdot 29 \\
4 \cdot 69 \\
4 \cdot 64 \\
4 \cdot 20 \\
4 \cdot 01 \\
3 \cdot 64 \\
3 \cdot 56 \\
3 \cdot 83 \\
3 \cdot 76 \\
4 \cdot 25 \\
3 \cdot 80 \\
3 \cdot 90 \\
3 \cdot 88 \\
3 \cdot 02 \\
3 \cdot 11 \\
3 \cdot 28 \\
2 \cdot 81 \\
2 \cdot 92\end{array}$ & $\begin{array}{l}9 \cdot 23 \\
8 \cdot 57 \\
8 \cdot 59 \\
8 \cdot 41 \\
7 \cdot 69 \\
7 \cdot 40 \\
7 \cdot 11 \\
7 \cdot 67 \\
7 \cdot 66 \\
8 \cdot 26 \\
7 \cdot 87 \\
7 \cdot 59 \\
7 \cdot 42 \\
5 \cdot 97 \\
5 \cdot 90 \\
6 \cdot 06 \\
4 \cdot 51 \\
5 \cdot 51\end{array}$ & $\begin{array}{l}5 \cdot 25 \\
4 \cdot 43 \\
4 \cdot 48 \\
4 \cdot 67 \\
4 \cdot 28 \\
4 \cdot 21 \\
4 \cdot 16 \\
4 \cdot 73 \\
4 \cdot 74 \\
4 \cdot 92 \\
4 \cdot 90 \\
4 \cdot 99 \\
5 \cdot 24 \\
4 \cdot 96 \\
5 \cdot 95 \\
6 \cdot 10 \\
5 \cdot 75 \\
7 \cdot 46\end{array}$ & $\begin{array}{l}4 \cdot 82 \\
4 \cdot 75 \\
4 \cdot 32 \\
4 \cdot 31 \\
4 \cdot 09 \\
4 \cdot 05 \\
3 \cdot 99 \\
4 \cdot 82 \\
4 \cdot 75 \\
4 \cdot 91 \\
4 \cdot 92 \\
4 \cdot 94 \\
4 \cdot 93 \\
4 \cdot 64 \\
5 \cdot 15 \\
5 \cdot 20 \\
4 \cdot 70 \\
-\end{array}$ & $\begin{array}{l}4 \cdot 23 \\
3 \cdot 35 \\
3 \cdot 27 \\
3 \cdot 44 \\
3 \cdot 40 \\
3 \cdot 10 \\
3 \cdot 24 \\
3 \cdot 20 \\
3 \cdot 98 \\
4 \cdot 79 \\
4 \cdot 92 \\
4 \cdot 89 \\
4 \cdot 87 \\
4 \cdot 48 \\
4 \cdot 96 \\
5 \cdot 54 \\
4 \cdot 84 \\
7 \cdot 33\end{array}$ & $\begin{array}{l}6 \cdot 40 \\
5 \cdot 69 \\
5 \cdot 51 \\
4 \cdot 66 \\
4 \cdot 61 \\
4 \cdot 40 \\
4 \cdot 83 \\
5 \cdot 33 \\
5 \cdot 52 \\
5 \cdot 93 \\
5 \cdot 69 \\
5 \cdot 52 \\
5 \cdot 73 \\
5 \cdot 16 \\
5 \cdot 79 \\
6 \cdot 80 \\
5 \cdot 23 \\
8 \cdot 20\end{array}$ \\
\hline Female & $\begin{array}{r}2 \\
3 \\
4 \\
5 \\
6 \\
7 \\
8 \\
9 \\
10 \\
11 \\
12 \\
13 \\
14 \\
15\end{array}$ & $\begin{array}{l}46 \\
38 \\
44 \\
45 \\
39 \\
60 \\
21 \\
80 \\
88 \\
94 \\
68 \\
65 \\
54 \\
30\end{array}$ & $\begin{array}{l}5 \cdot 09 \\
4 \cdot 74 \\
4 \cdot 99 \\
4 \cdot 64 \\
5 \cdot 10 \\
4 \cdot 90 \\
5 \cdot 05 \\
5 \cdot 30 \\
5 \cdot 37 \\
5 \cdot 89 \\
5 \cdot 34 \\
5 \cdot 87 \\
6 \cdot 15 \\
6 \cdot 31\end{array}$ & $\begin{array}{r}9 \cdot 83 \\
8 \cdot 90 \\
9 \cdot 34 \\
8 \cdot 65 \\
9 \cdot 30 \\
8 \cdot 62 \\
9 \cdot 23 \\
9 \cdot 35 \\
9 \cdot 44 \\
9 \cdot 64 \\
9 \cdot 21 \\
9 \cdot 45 \\
10 \cdot 13 \\
10 \cdot 19\end{array}$ & $\begin{array}{l}4 \cdot 75 \\
4 \cdot 90 \\
4 \cdot 88 \\
4 \cdot 98 \\
5 \cdot 09 \\
5 \cdot 88 \\
5 \cdot 95 \\
6 \cdot 15 \\
7 \cdot 30 \\
7 \cdot 09 \\
7 \cdot 97 \\
9 \cdot 10 \\
9 \cdot 44\end{array}$ & $\begin{array}{l}5 \cdot \overline{22} \\
5: 00 \\
4 \cdot 82 \\
5 \cdot 34 \\
5 \cdot 64 \\
6 \cdot 07 \\
6 \cdot 42 \\
6 \cdot 64 \\
7 \cdot 43 \\
6 \cdot 90 \\
8 \cdot 22 \\
8 \cdot 52 \\
9 \cdot 11\end{array}$ & $\begin{array}{l}4 \cdot \overline{03} \\
3 \cdot 90 \\
3 \cdot 67 \\
4 \cdot 34 \\
4 \cdot 25 \\
4 \cdot 77 \\
5 \cdot 04 \\
4 \cdot 78 \\
5 \cdot 39 \\
5 \cdot 64 \\
6 \cdot 73 \\
6 \cdot 45 \\
7 \cdot 05\end{array}$ & $\begin{array}{r}\overline{6 \cdot 42} \\
6 \cdot 78 \\
5 \cdot 87 \\
7 \cdot 14 \\
6 \cdot 68 \\
7 \cdot 56 \\
7 \cdot 83 \\
8 \cdot 56 \\
9 \cdot 83 \\
10 \cdot 16 \\
11 \cdot 07 \\
12 \cdot 60 \\
12 \cdot 41\end{array}$ \\
\hline
\end{tabular}

"Caliper results converted to equivalent $x$-ray measurement of subcutaneous tissue. 
thickness; anyone using his own pattern of caliper has only to calibrate his results against $x$-ray photographs at the same sites to give comparable figures.*

EFFect of Different Conditions on MeasureMENTS OF BoDY FAT.-The effects of sex and age on fat thickness at different measuring sites have already been shown in Table IV and Figs 1 to 3 . The data have also been broken down in terms of nutritional grading (by means of a clinical examination), and into a general measure of social class (from the type of school which the children attended and the neighbourhoods from which they came).

The numbers in the poor nutritional grade are too low to justify setting out the mean measurements separately for each age, and, as we are not primarily interested in the age differences within these groups, the mean figures are given for different nutritional categories and social groups relative to the equivalent age standards.

Nutritional Status.-The nutritional criterion is two-fold, consisting either of those children among the general population who were downgraded at the clinical examination (for method see Adcock, Hammond, and Magee, 1947), or of special groups of children who were selected as suffering from general debility or as being undernourished and in need of special treatment.

*It might be thought that if caliper measurements have to be calibrated according to $x$-ray results it would be much better to use $x$-rays in the beginning. However, the $x$-ray figures are probably rather $x$-rays in the beginning. Howeible than the standard caliper results and there are less reproducible than the standard caliper results and there are studies, added to which the choice of measuring sites for $x$-rays is more limited.
All the groups classified as being poorly nourished are below the general average for their age, but it is interesting to find that the well nourished children frequently show much less difference from the standard, and in some groups are even thinner than the standard on average (Table VI).

Social Status.-The children were divided into three groups: a "superior" group, consisting of children attending fee-paying day and boarding schools, whose parents belonged mostly to the professional classes; a "good" group, in which the children attended better-class schools in prosperous neighbourhoods and whose parents were mostly from Social Class III; and a "poor" group, drawn from children of Social Classes IV and V in "slums."

It is noteworthy that those from the poorest districts always give mean results below the standards for their age, but occasionally children from the highest social class give lower results than those from the good average group. There is certainly no social gradient in body fat comparable with that in weight and height in school children (Table VII, opposite).

Calculation of Amount of Body Fat.-The above results, which are given in the form of caliper measurements, are suitable for comparative purposes, but it would be useful to be able to calculate the actual weight of surface fat present, so that actual losses or gains could be calculated, e.g. in periods of stress. In principle, the measurement of the uncompressed thickness of surface fat and the areas of the body over which these thicknesses apply are all that are required, but in practice, many fat

TABLE VI

SKINFOLD FAT MEASUREMENTS FOR DIFFERENT NUTRITIONAL GRADES

\begin{tabular}{|c|c|c|c|c|c|c|c|c|c|c|}
\hline \multirow{2}{*}{ Sex } & \multirow{2}{*}{ 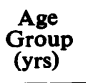 } & \multirow{2}{*}{\multicolumn{2}{|c|}{ Nutrition }} & \multirow{2}{*}{$\begin{array}{l}\text { Number } \\
\text { Examined }\end{array}$} & \multicolumn{6}{|c|}{ Measurement Site } \\
\hline & & & & & Biceps & Triceps & Sub-scapular & Supra-iliac & Sub-costal & Abdominal \\
\hline \multirow{6}{*}{ Male } & \multirow{3}{*}{$5-10$} & "Poor" & .. & 34 & $3 \cdot 93$ & $7 \cdot 35$ & $4 \cdot 31$ & $4 \cdot 10$ & $3 \cdot 85$ & $4 \cdot 75$ \\
\hline & & "Good" & $\ldots$ & 27 & $4 \cdot 92$ & $9 \cdot 70$ & $5 \cdot 85$ & $5 \cdot 93$ & 3.95 & $6 \cdot 78$ \\
\hline & & Standard & . & - & $4 \cdot 00$ & $8 \cdot 00$ & $4 \cdot 70$ & $4 \cdot 50$ & 3.90 & $5 \cdot 20$ \\
\hline & \multirow{3}{*}{$11-15$} & "Poor" & .. & 37 & $3 \cdot 76$ & $6 \cdot 15$ & 4.01 & $3 \cdot 78$ & $3 \cdot 37$ & $4 \cdot 00$ \\
\hline & & "Good" & . & 27 & $4 \cdot 81$ & $9 \cdot 21$ & $5 \cdot 95$ & $5 \cdot 52$ & $4 \cdot 34$ & $7 \cdot 13$ \\
\hline & & Standard & .. & - & $4 \cdot 26$ & $8 \cdot 33$ & $5 \cdot 30$ & $5 \cdot 22$ & $5 \cdot 15$ & $6 \cdot 00$ \\
\hline \multirow{6}{*}{ Female } & \multirow{3}{*}{$5-10$} & "Poor" & . & 46 & $4 \cdot 70$ & $7 \cdot 16$ & 5.06 & 5.00 & $3 \cdot 00$ & $4 \cdot 85$ \\
\hline & & “Good" & .. & 28 & $5 \cdot 58$ & $12 \cdot 28$ & $5 \cdot 99$ & $7 \cdot 30$ & $6 \cdot 25$ & $7 \cdot 88$ \\
\hline & & Standard & $\ldots$ & - & $5 \cdot 36$ & $9 \cdot 85$ & $5 \cdot 80$ & $6 \cdot 20$ & $4 \cdot 77$ & $7 \cdot 95$ \\
\hline & \multirow{3}{*}{$11-15$} & "Poor" & . & 60 & 5.05 & $8 \cdot 28$ & $6 \cdot 28$ & $6 \cdot 48$ & $5 \cdot 06$ & $9 \cdot 40$ \\
\hline & & "Good" & . & 30 & 6.04 & $10 \cdot 26$ & $7 \cdot 71$ & $8 \cdot 31$ & $6 \cdot 72$ & $12 \cdot 19$ \\
\hline & & Standard & .. & - & $6 \cdot 15$ & $10 \cdot 58$ & $8 \cdot 48$ & $8 \cdot 38$ & $6 \cdot 66$ & $12 \cdot 60$ \\
\hline
\end{tabular}


measurements and many measurements of lengths and girths of different parts of the body are required. However, we can make use of the fact that fat measurements taken at a few sites are related closely to those at most sites, and hence we can estimate thicknesses at some of the sites. Further, we can estimate the total surface area, e.g. from Du Bois (1936) or from similar formulae, and "weight" this by a simple or weighted mean of the fat thicknesses throughout the body (the weights being determined by the area of the body over which the thickness applies). Experiments now being carried on, if confirmed, indicate that estimations of surface body fat sufficiently accurate for practical purposes can probably be made from a few measuring sites used in conjunction with weight and height and a very few additional body measurements.

\section{Discussion}

The measurements of skinfold thickness at any one site can be used for comparative purposes in nutritional or anthropometric surveys, just like any other measurements. However, the main justification for using skinfold measurements depends on whether the information they give applies to surface fat generally rather than to the particular sites measured. The experience obtained with such measurements over the past 10 years and the published work of Brožek and Keyes (1951) and of
Edwards (1950) indicate that the pattern of fat deposition which applies to any one site applies closely to all other sites. The present paper has given a measure of the general influences operating, in the form of the percentage of the variance due to a common or general factor influence and the multiple correlations between combinations of a few measurements and total body fat. The contribution of the general influences is far higher than in any other anthropometric measurements. Thus, for example, one fat measurement will indicate far more about the general amount and distribution of body fat on a person than one physical measurement will tell us about a person's general size and shape. This is a finding of great practical importance, because it means that only a very few sites need to be measured in order to compare the general amount of body fat of persons or groups. It is doubtful whether any improvement in the representativeness of the measures for general nutritional purposes which might result from new combinations of sites would justify more intensive research into this problem. However, for studying clinically the changes in the distribution and amount of body fat which may occur with age, or with special diets, and so on,differences in the pattern of fat deposition may be important, and many more sites may then need to be measured. The sites used in this study are among those which have proved most convenient to take in the field

TABLE VII

SKINFOLD FAT MEASUREMENTS FOR DIFFERENT SOCIAL LEVELS

\begin{tabular}{|c|c|c|c|c|c|c|c|c|c|c|}
\hline \multirow{2}{*}{ Sex } & \multirow{2}{*}{$\begin{array}{c}\text { Age } \\
\text { Group } \\
\text { (yrs) }\end{array}$} & \multirow{2}{*}{\multicolumn{2}{|c|}{ Social Grade }} & \multirow{2}{*}{$\begin{array}{c}\text { Number } \\
\text { Examined }\end{array}$} & \multicolumn{6}{|c|}{ Measurement Site } \\
\hline & & & & & Biceps & Triceps & Sub-scapular & Supra-iliac & Sub-costal & Abdominal \\
\hline \multirow{8}{*}{ Male } & \multirow{4}{*}{$5-10$} & "Superior" & & 27 & $4 \cdot 08$ & $9 \cdot 21$ & $4 \cdot 90$ & $5 \cdot 08$ & $4 \cdot 56$ & $5 \cdot 13$ \\
\hline & & "Good" & $\ldots$ & 184 & $4 \cdot 34$ & $8 \cdot 48$ & $5 \cdot 09$ & $5 \cdot 00$ & $3 \cdot 92$ & $5 \cdot 40$ \\
\hline & & "Poor" & . & 93 & $3 \cdot 52$ & $6 \cdot 89$ & $4 \cdot 16$ & $4 \cdot 11$ & 一 & $4 \cdot 28$ \\
\hline & & Standard & .. & - & $4 \cdot 06$ & $8 \cdot 00$ & $4 \cdot 70$ & $4 \cdot 62$ & $3 \cdot 88$ & $5 \cdot 23$ \\
\hline & \multirow{4}{*}{$11-15$} & "Superior" & & 160 & $4 \cdot 17$ & $8 \cdot 57$ & $5 \cdot 90$ & $5 \cdot 77$ & $6 \cdot 31$ & $6 \cdot 76$ \\
\hline & & “Good" & . & 50 & $4 \cdot 47$ & $9 \cdot 36$ & $5 \cdot 40$ & $5 \cdot 57$ & - & $6 \cdot 59$ \\
\hline & & "Poor" & . & 117 & $3 \cdot 64$ & $7 \cdot 25$ & $4 \cdot 63$ & $4 \cdot 85$ & $-\cdot$ & $5 \cdot 12$ \\
\hline & & Standard & . & 一 & $4 \cdot 07$ & $7 \cdot 94$ & $5 \cdot 30$ & $5 \cdot 17$ & $5 \cdot 09$ & $5 \cdot 91$ \\
\hline \multirow{8}{*}{ Female } & \multirow{4}{*}{$5-10$} & "Superior" & & 93 & $5 \cdot 78$ & $12 \cdot 22$ & - & - & - & 一 \\
\hline & & "Good" & . & 178 & $5 \cdot 78$ & $10 \cdot 30$ & $6 \cdot 20$ & $6 \cdot 54$ & - & $8 \cdot 30$ \\
\hline & & "Poor" & . & 103 & $4 \cdot 46$ & $9 \cdot 07$ & - & - & - & - \\
\hline & & Standard & . & - & $5 \cdot 47$ & $9 \cdot 84$ & $5 \cdot 82$ & $6 \cdot 62$ & - & $8 \cdot 10$ \\
\hline & \multirow{4}{*}{$11-15$} & "Superior" & & 137 & $6 \cdot 64$ & $12 \cdot 38$ & - & - & - & - \\
\hline & & "Good" & .. & 50 & $6 \cdot 35$ & $10 \cdot 70$ & $7 \cdot 52$ & $7 \cdot 90$ & - & $11 \cdot 03$ \\
\hline & & "Poor" & .. & 135 & $4 \cdot 80$ & 8.98 & - & - & - & - \\
\hline & & Standard & . & - & $6 \cdot 12$ & $10 \cdot 60$ & 8.03 & $8 \cdot 32$ & - & $11 \cdot 88$ \\
\hline
\end{tabular}

The results for a particular measurement are not given unless the measurements were available for all children. 
An admirable discussion of these and similar practical points is given by Edwards (1955).

The present standards are fairly complete for the younger age groups, although they should be regarded as purely provisional until more widespread measuring has been undertaken, e.g. by local health authorities. Figures covering the adolescent period in detail and different adult populations are particularly needed.

The distribution of caliper measurements of subcutaneous fat has been found to be positively skewed in much the same way as weight is skewed. Thus it is easily possible for a person to exceed the mean measurement by more than its own value at some sites, but he cannot be below the mean by this amount or he would have a negative thickness! The biological basis is that the fats apparently do not increase or decrease arithmetically; instead they appear to change proportionally, and therefore, as pointed out by Edwards and others (1950), a logarithmic transformation has some advantage. This is consistent with the "cellular" mechanism for fat deposition suggested by Edwards (1950). It is possible that the normal variability is being increased by the addition of what are really pathological cases (the obese children) in the population. The skewness probably has little effect on the interpretation of differences between group means since these mostly occur near the mode where the skewness is a minimum. However, a caution is necessary when considering very large measurements in the case of individual children. These should not be assumed to have the rarity which would apply to the corresponding $\frac{x}{\sigma}$ deviation in a normally distributed population. Since a logarithmic transformation gives an approximately normal curve, this can be used to compare the frequency of the logarithm of an actual measurement (and hence the corresponding absolute value). Alternatively, percentile points* of the data can be given when reporting fat measurements, provided that the numbers in the investigation are sufficient for the purpose. However, I think that it is more important to be concerned about an absolute level of fat in a child rather than with his position on an assumed distribution. The problem then becomes a clinical one of saying what is a suitable level beyond which body fat impairs functioning, e.g., through extra strain on the heart or lowered mechanical efficiency, or in the case of leanness through affording insufficient thermal insulation. Extremes of body fat may also, of course,

\footnotetext{
*It is possible to use a logarithmic transformation as a device for smoothing an observed distribution, and the calculation of percentiles can then be made and translated back into actual fat values based on such smooth curves. Alternatively, simple graphical smoothing of observed results can be used.
}

be associated with other pathological conditions, such as disorders of the endocrine system.

A further caution concerning the interpretation of fat measurements is perhaps relevant: the analysis of cross-sectional measurements in children (Hammond, 1953a) has shown that the major physical types consist of leptosomes and pyknics, and that subcutaneous fat over the arm is one of the main type differentiators; subcutaneous fat has much higher saturation with the type factor than has weight, for example. In this paper it is also shown that whilst there is evidence that the leptosomes (especially if they are also small) tend to be more often clinically inferior in the sense of being downgraded more often and showing more clinical signs indicative of inadequate nutrition-yet the great majority of leptosome children are healthy and we should take this as a warning not to regard a low fat measurement as a necessarily adverse sign. A recent or sudden loss of body fat is much more important than general thinness. Nevertheless, standards of body fat at different ages provide a useful guide in selecting children for special investigation and treatment.

I should like to advocate the method of expressing fat measurements relative to the $x$-ray thickness of uncompressed fat. This seems to me to be the most logical form of standardization, and it is superior to any standardization in terms of a particular design of instrument. For, however good that instrument may be, or however widely it may be used, there is still an element of compression of the skinfold and, moreover, of compression which may differ at different thickness readings.

\section{SUMMARY}

(1) Results of measuring subcutaneous fat at different sites on the body have been correlated with each other to see which sites are the most representative of those measured, both in respect of the total subcutaneous fat for the individual at any moment and in respect of changes in fat with age.

(2) Measures used for indicating the degree of agreement are the correlations between each site and the sum of all the sites measured, and also the saturations for the general factor for surface body fat.

(3) All the measurements were found to be highly representative of total fat. When used in combination, the best measurements for determining total fat were those taken at the biceps or triceps plus those at the sub-scapular and abdominal regions.

(4) Standards for body fat measurements based on over 4,500 subjects calibrated according to M.R.C. calipers of plate size $6 \times 15 \mathrm{~mm}$. and 
pressure $10 \mathrm{~g} . / \mathrm{mm}^{2}$ for boys and girls from age 2 years upwards are given for biceps, triceps, subscapular, sub-costal, supra-iliac and abdominal regions. Standard errors at the different ages are also included.

(5) The caliper measurements have been transformed into equivalent actual fat thickness as measured from $x$-ray photographs.

(6) Mean measurements for different nutritional and social groups descend from good to poor nutrition and from high to low social class, but the highest groups in both cases show little difference from the age standards.

(7) The frequency distribution of subcutaneous fat measurements is positively skewed, and it is suggested that this may be partly due to the inclusion of a condition of obesity acting as a separate entity. Research is needed to differentiate over-fat or overthin children on clinical grounds of health and optimal functioning.

(8) Methods of estimating the total quantity of subcutaneous fat in the body from measurements of surface area and a representative set of caliper measurements are being studied.

I should like to express my indebtedness to Drs. W. T. C. Berry and P. J. Cowin for permission to include many of their measurements of body fat in the Table of Norms. I am also most grateful to Dr. J. M. Tanner and Mr. R. Whitehouse for making available the extensive series of comparisons between caliper and $x$-ray measurements obtained during the Harpenden Growth Study from which I calculated the regression equation. Dr. D. A. W. Edwards has also very kindly allowed me to make use of his data on fat measurements in women. From these the National Physical Laboratories calculated the Tables of Correlations which I have analysed. I should also like to acknowledge the help given by Dir. E. R. Bransby in organizing the field trials, and for helpful criticism throughout the investigation.

\section{REFERENCES}

Adcock, E. W., Hammond, W. H., and Magee, H. E. (1947). J. Hyg., 45, 65 .

Berry, W. T. C. (1951). Monthly Bull. Min. Hlth. Lab. Serv., 10, 155. - and Cowin, P. J. (1951). Med. Offr., 85, 213.

- - (1954). Brit. J. Nutrit., 8, 79.

Brozek, J., and Keys, A. (1951). Ibid., 5, 194.

Draper, G. (1924). "Human Constitution: a Consideration of its Relationship to Disease", p. 209 et seq. Saunders, Philadelphia.

Du Bois, E. F. (1936). "Basal Metabolisim in Health and Disease", 3rd ed., p. 129. Lea and Febiger, Philadelphia.

Edwards, D. A. W. (1950). Clin. Sci., 9, 259.

- (1955). Voeding, 16, 57.

- Hammond, W. H., Healy, M. J. R., Tanner, J. M., and Whitehouse, R. H. (1955). Brit. J. Nutrit., 9, 133.

Freeman, W. (1934). Ann. intern. Med., 7, 805.

Hammond, W. H. (1953a). Hum. Biol., 25, 65.

- (1953b). British Journal of Preventive and Social Medicine, 7, 231.

Tanner, J. M. (1955). "Growth at Adolescence". Blackwell, Oxford.

\section{APPENDIX}

\section{Measuring Sirtes}

Forearm: Lateral surface half-way along.

Forearm: Proximal surface half-way along.

Biceps: Median line over middle of biceps.

Upper Arm: Lateral, midway between acromial edge and olecron.

Triceps: Half-way down the back of the arm over the triceps.

Triceps: Top of triceps.

Sub-scapular: Immediately below inferior angle of scapula following the natural fold at an angle approximately $45^{\circ}$ to the vertical.

Inter-scapular: Between lowest points of scapulae.

Supra-iliac: Immediately above the left iliac crest.

Sub-costal: Immediately under the costal margin vertically below the nipple.

Abdominal: About 1 inch to left of and below umbilicus.

Lower Leg: Lateral, below head of tibia.

Under Chin:

Thigh: Median line 2 in. above patella.

Thigh: Mid-thigh lateral.

Pectoral: Below clavicle in nipple line.

\section{CoRrigendum}

In an article by Kirk, Shield, Stenhouse, Bryce and Jakobowicz, Brit. J. prev. soc. Med. (1955), 9, 104, in the heading of Table VII on p. 108 for $\chi^{2}, \operatorname{read} \chi$. 